\title{
Faktor Risiko Nyeri Punggung Bawah pada Dokter Gigi di Sulawesi Utara
}

\author{
Juliatri, ${ }^{1}$ Diana V. D. Doda, ${ }^{1,2,4}$ Ora Et Labora I. Palandeng ${ }^{1,3,4}$
}

\author{
${ }^{1}$ Pascasarjana Program Studi Ilmu Kesehatan Masyarakat Universitas Sam Ratulangi, \\ Manado, Indonesia \\ ${ }^{2}$ Bagian Fisiologi Fakultas Kedokteran Universitas Sam Ratulangi, Manado, Indonesia \\ ${ }^{3}$ Bagian THT-KL Fakultas Kedokteran Universitas Sam Ratulangi, Manado, Indonesia \\ ${ }^{4}$ Fakultas Kesehatan Masyarakat Universitas Sam Ratulangi, Manado, Indonesia \\ Email: juliatri31@unsrat.ac.id; vandadoda@unsrat.ac.id
}

\begin{abstract}
Modern design of dental equipment does not totally prevent the profession from experiencing low back pain (LBP). This study was aimed to determine the prevalence of LBP, to analyze risk factors associated with LBP, and to analyze risk factor for LBP among dentists in North Sulawesi. This was a quantitative and analytical study with a cross sectional design. Samples were determined by using the purposive sampling method, namely 148 dentists who met the inclusion criteria. Data were collected by using the Ovako Working Posture Analysis System (OWAS) questionnaire to assess the posture of the dentists during treatment by adding individual and occupational characteristics. Further data were analyzed univariately, bivariately, and multivariately by using the SPSS program. The results showed that the prevalence of dentists who experienced LBP was $41,2 \%$. In addition, work position ( $\mathrm{p}=0.043$, correlation coefficient $\Phi=0.166)$, and the number of patients in a day $(\mathrm{p}=0.025, \mathrm{r}=0.190)$ had a significant correlation with NPB. In conclusion, work position is the most influential factor of LBP among dentists in North Sulawesi $(\mathrm{OR}=2.085, \mathrm{CI}=95 \%)$. It is expected that all dentists should avoid working positions that could harm their musculoskeletal systems.
\end{abstract}

Keywords: low back pain, dentist

\begin{abstract}
Abstrak: Perubahan desain peralatan kedokteran gigi yang semakin mutakhir tidak menjadikan profesi dokter gigi terbebas dari keluhan nyeri punggung bawah (NPB). Penelitian ini bertujuan untuk mengetahui prevalensi NPB dan menganalisis faktor risiko NPB pada dokter gigi di Sulawesi Utara. Jenis penelitian ialah analitik kuantitatif dengan desain potong lintang. Penentuan sampel dengan metode purposive sampling yaitu sebanyak 148 dokter gigi yang memenuhi kriteria inklusi. Data dikumpulkan menggunakan kuesioner Ovako Working Posture Analysis System (OWAS) untuk menilai postur tubuh dokter gigi saat melakukan perawatan dengan menambahkan karakteristik individu dan pekerjaan. Data selanjutnya dianalisis univariat, bivariat, dan multivariat dengan program SPSS. Hasil penelitian menunjukkan prevalensi dokter gigi yang mengalami NPB sebesar $41,2 \%$. Selain itu posisi kerja $(\mathrm{p}=0,043$, koefisien korelasi $\Phi=0,166)$, dan jumlah pasien per hari $(\mathrm{p}=0,025, \mathrm{r}=0,190)$ memiliki korelasi yang bermakna dengan NPB. Simpulan penelitian ini ialah posisi kerja merupakan faktor yang paling berpengaruh terhadap NPB pada dokter gigi di Sulawesi Utara ( $\mathrm{OR}=2,085, \mathrm{CI}=95 \%)$. Diharapkan bagi seluruh dokter gigi dapat menghindari posisi kerja yang dapat membahayakan sistem muskuloskeletal saat melakukan perawatan kepada pasien.
\end{abstract}

Kata kunci: nyeri punggung bawah, dokter gigi

\section{PENDAHULUAN}

Dokter gigi merupakan salah satu profesi yang berisiko tinggi mengalami sejum- lah bahaya akibat pekerjaan seperti nyeri punggung bawah (NPB). ${ }^{1}$ Moodley et $\mathrm{al}^{2}$ mengungkapkan bahwa meskipun desain 
peralatan kedokteran gigi semakin mutakhir, gangguan muskuloskeletal tetap menjadi masalah kesehatan akibat pekerjaan yang paling banyak diderita oleh dokter gigi.

Prevalensi NPB di beberapa negara menunjukkan persentase yang bermakna setiap tahun. ${ }^{3}$ Penelitian yang dilakukan terhadap 110 dokter gigi di Hizar India, menunjukkan bahwa $30 \%$ responden mengalami NPB. ${ }^{4}$ Penelitian serupa juga dilakukan di Pune India dan melaporkan sebesar $62,1 \%$ dari dokter gigi yang diteliti menderita NPB. ${ }^{5}$ Pada penelitian yang dilakukan di Arab Saudi terhadap 60 dokter gigi dilaporkan $47,6 \%$ menderita NPB. ${ }^{6}$

Prevalensi NPB pada dokter gigi di Indonesia juga pernah dilaporkan oleh Ulya $^{7}$ yang melakukan penelitian di seluruh wilayah kerja klinik dokter gigi Surabaya. Dari 31 dokter gigi yang menjadi sampel, seluruhnya (100\%) mengalami NPB. Penelitian serupa juga pernah dilakukan pada dokter gigi di Yogyakarta. Dari penelitian tersebut, sebanyak 39 dokter gigi (51\%) menderita NPB dengan berbagai tingkat keparahan. ${ }^{3}$ Penelitian yang dilakukan oleh Sawitri dan Mulyono ${ }^{8}$ terhadap dokter gigi di Probolinggo menunjukkan risiko yang paling sering diderita oleh dokter gigi yakni gangguan muskuloskeletal. Dari penelitian tersebut, keluhan nyeri pada tulang belakang dialami oleh beberapa dokter gigi di Kota Probolinggo.

Tingginya prevalensi NPB pada dokter gigi dapat menyebabkan pelayanan kepada masyarakat menjadi tidak maksimal. Gangguan kesehatan yang dialami oleh dokter gigi seperti NPB dapat menurunkan kualitas pelayanan kesehatan gigi dan mulut. Hal ini didukung oleh beberapa penelitian yang melaporkan bahwa NPB menyebabkan penurunan aktivitas kehidupan seharihari dan mengurangi waktu aktivitas kerja hampir 5 jam per minggu. ${ }^{9-11}$

Nyeri punggung bawah pada dokter gigi dapat disebabkan oleh faktor individu ${ }^{12,13}$ dan faktor pekerjaan. ${ }^{14}$ Faktor individu yang dikaitkan dengan NPB antara lain usia dokter gigi. Prevalensi NPB meningkat seiring bertambahnya usia, dengan puncaknya pada usia antara 35-55 tahun. Selain itu, penelitian epidemiologi NPB di Amerika Serikat menunjukkan peningkatan di seluruh kelompok usia baik pada laki-laki maupun perempuan. ${ }^{11}$

Faktor pekerjaan seperti posisi saat bekerja juga dikaitkan dengan terjadinya NPB pada dokter gigi. Pergerakan yang terbatas dan bidang visual sempit yang berhubungan dengan rongga mulut sering menyebabkan seorang dokter gigi mengambil posisi tubuh yang tidak ergonomi untuk mencapai akses dan visibilitas yang baik di dalam rongga mulut. ${ }^{15}$

Profesi dokter gigi bekerja dalam posisi berdiri atau duduk, sedangkan pasien dalam posisi telentang atau berbaring pada kursi gigi. Hal ini membuat dokter gigi sering kali harus memutar tubuh dan membungkuk untuk melakukan perawatan gigi. ${ }^{5}$ Selain itu, prosedur perawatan gigi biasanya panjang dan membutuhkan konsentrasi tinggi selama bekerja. ${ }^{15}$ Posisi canggung yang berkepanjangan dan postur tubuh statis sering kali tidak dapat dihindari oleh seorang dokter gigi. ${ }^{16}$

Sejumlah penelitian mengenai NPB pada dokter gigi telah dilakukan di beberapa negara di luar negeri dan di Indonesia. Tentunya terdapat perbedaan karakteristik individu dan pekerjaan di tiap-tiap daerah. Selain itu keadaan demografi seperti rasio dokter gigi dengan penduduk yang dapat memengaruhi beban pekerjaan dokter gigi tidaklah sama di setiap daerah. Penelitian mengenai faktor risiko yang dapat menyebabkan NPB pada dokter gigi di Sulawesi Utara belum pernah dilakukan; oleh karena itu, penulis terdorong untuk melakukan penelitian terkait hal tersebut.

\section{METODE PENELITIAN}

Jenis penelitian ialah survei analitik kuantitatif dengan desain potong lintang. Penelitian dilaksanakan pada dokter gigi di Sulawesi Utara pada bulan September 2020 sampai Maret 2021.

Populasi penelitian ini yaitu seluruh dokter gigi yang terdaftar sebagai anggota Persatuan Dokter Gigi Indonesia (PDGI) cabang Manado berjumlah 234 orang per 
Agustus 2020. ${ }^{17}$ Pengambilan sampel menggunakan metode purposive sampling yakni seluruh anggota populasi dokter gigi yang memenuhi kriteria inklusi berjumlah 148 orang. Kriteria inklusi yaitu bersedia menjadi responden dan telah melakukan praktik kedokteran gigi minimal 1 tahun. Responden yang berusia di atas 45 tahun, dalam kondisi hamil, menderita tumor tulang belakang, penyakit ginjal, endometriosis, fraktur tulang belakang akibat kecelakaan atau terjatuh, osteoartritis, dan reumatoid artritis dieksklusi dari penelitian.

Data dikumpulkan menggunakan kuesioner Ovako Working Posture Analysis System (OWAS) untuk menilai postur tubuh dokter gigi saat melakukan perawatan dengan menambahkan karakteristik individu dan pekerjaan yang diisi secara online.

Metode OWAS merupakan salah satu metode untuk melakukan pengukuran postur tubuh yang berisiko mengakibatkan kecelakaan kerja pada bagian muskuloskeletal. Metode ini menilai postur kerja pada bagian punggung, lengan, kaki, dan berat beban yang diangkat (Gambar 1). ${ }^{18}$ Setiap sikap kerja pada masing-masing bagian tubuh diberi kode (Tabel 1), ${ }^{19}$ lalu diklasifikasikan dalam tabel perhitungan metode OWAS (Tabel 2). ${ }^{18}$

Hasil perhitungan metode OWAS dibagi menjadi empat kategori yaitu kategori 1, 2, 3, dan 4. ${ }^{19}$ Kategori 1 OWAS diklasifikasikan sebagai posisi kerja normal, sedangkan kategori 2, 3 dan 4 OWAS diklasifikasikan sebagai posisi kerja tidak normal karena dapat membahayakan sistem muskuloskeletal.

Faktor individu meliputi usia, jenis kelamin, indeks massa tubuh (IMT), perilaku merokok, dan kebiasaan olahraga.

Faktor pekerjaan terdiri atas posisi bekerja, lama bekerja, jumlah pasien per hari, lama praktik. dan jenis perawatan yang paling sering dilakukan. Restorasi dan ekstraksi gigi dikategorikan sebagai jenis perawatan berisiko, sedangkan skeling dan ortodontik dikategorikan sebagai jenis perawatan tidak berisiko.

Data selanjutnya dianalisis secara univariat, bivariat, dan multivariat dengan program SPSS. Untuk mengetahui hubungan antara usia, IMT, lama bekerja, jumlah pasien per hari, dan lama praktik dengan kejadian NPB digunakan uji korelasi Point Biserial, sedangkan untuk menganalisis hubungan antara jenis kelamin, kebiasaan olahraga, posisi bekerja, dan jenis perawatan dengan NPB digunakan uji korelasi Phi pada analisis bivariat. Pada analisis multivariat, untuk mengetahui faktor risiko yang paling berpengaruh terhadap NPB digunakan analisis regresi logistik biner.

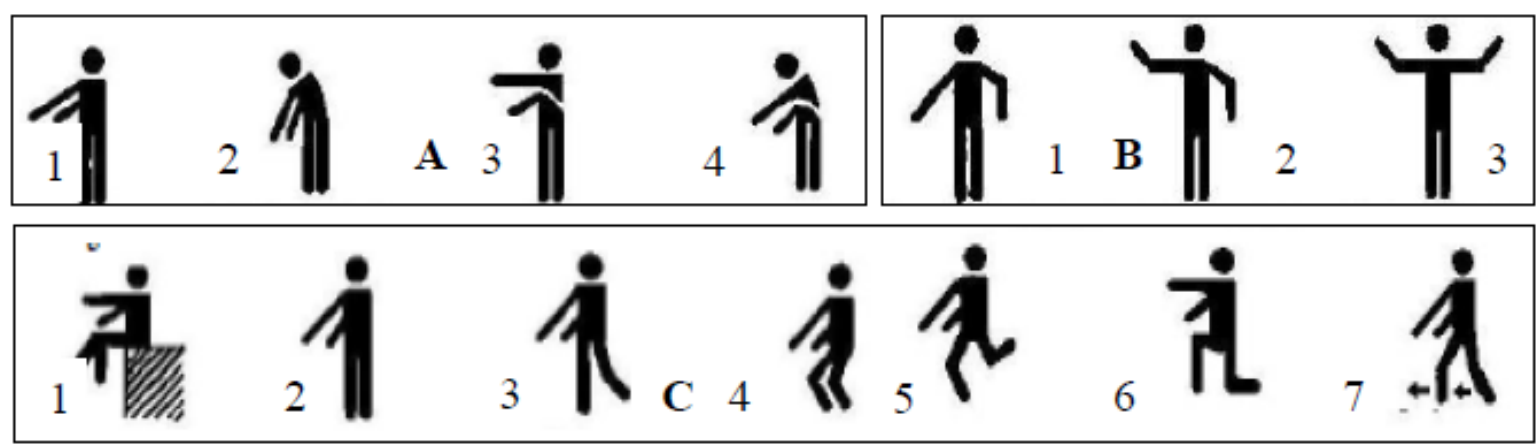

Gambar 1. Posisi dan kode sikap tubuh menggunakan metode OWAS: A. Sikap punggung: 1. Lurus/tegak; 2. Membungkuk; 3. Miring ke samping atau memutar; 4. Miring ke samping dan membungkuk ke depan. B. Sikap lengan: 1. Lengan kiri dan kanan berada di bawah bahu; 2. Salah satu lengan berada di atas bahu; 3. Lengan kiri dan kanan berada di atas bahu. C. Sikap kaki: 1 . Duduk; 2. Berdiri dan bertumpu pada kedua kaki yang lurus; 3. Berdiri dan bertumpu pada satu kaki lurus; 4. Berdiri dan bertumpu pada kedua kaki dengan lutut ditekuk; 5. Berdiri dan bertumpu pada satu kaki dengan lutut ditekuk; 6. Berlutut pada salah satu atau kedua lutut; 7. Berjalan. Sumber: Sriyanto dan Adwitya, 2018. ${ }^{18}$ 
Tabel 1. Pemberian kode sikap bagian tubuh menggunakan metode OWAS ${ }^{19}$

\begin{tabular}{lc}
\hline Sikap punggung & Kode \\
\hline Lurus & 1 \\
Membungkuk & 2 \\
Miring ke samping atau memutar & 3 \\
Miring ke samping dan membungkuk ke depan & 4 \\
Sikap Lengan & \\
Lengan kiri dan kanan berada di bawah bahu & 1 \\
Salah satu lengan berada di atas bahu & 2 \\
Lengan kiri dan kanan berada di atas bahu & 3 \\
Sikap kaki & \\
Duduk & 1 \\
Berdiri dan bertumpu pada kedua kaki yang lurus & 2 \\
Berdiri dan bertumpu pada satu kaki lurus & 3 \\
Berdiri dan bertumpu pada kedua kaki dengan lutut yang ditekuk & 4 \\
Berdiri dan bertumpu pada satu kaki dengan lutut ditekuk & 5 \\
Berlutut pada salah satu atau kedua lutut & 6 \\
Berjalan & 7 \\
Berat beban & \\
Berat beban <10kg & 1 \\
Berat beban $10-\leq 20$ kg & 2 \\
Berat beban > 20kg & 3 \\
\hline
\end{tabular}

Tabel 2. Hasil perhitungan dengan metode $\mathrm{OWAS}^{18}$

\begin{tabular}{ccccccccccccccccccccccccc}
\hline $\begin{array}{l}\text { Pung- } \\
\text { gung }\end{array}$ & $\begin{array}{l}\text { Le- } \\
\text { ngan }\end{array}$ & 1 & 2 & 3 & 1 & 2 & 3 & 1 & 2 & 3 & 1 & 2 & 3 & 1 & 2 & 3 & 1 & 2 & 3 & 1 & 2 & 3 & Beban \\
\hline \multirow{3}{*}{1} & 1 & 1 & 1 & 1 & 1 & 1 & 1 & 1 & 1 & 1 & 2 & 2 & 2 & 2 & 2 & 2 & 1 & 1 & 1 & 1 & 1 & 1 & \\
& 2 & 1 & 1 & 1 & 1 & 1 & 1 & 1 & 1 & 1 & 2 & 2 & 2 & 2 & 2 & 2 & 1 & 1 & 1 & 1 & 1 & 1 & \\
& 3 & 1 & 1 & 1 & 1 & 1 & 1 & 1 & 1 & 1 & 2 & 2 & 2 & 2 & 2 & 2 & 1 & 1 & 1 & 1 & 1 & 1 & \\
& 1 & 2 & 2 & 3 & 2 & 2 & 3 & 2 & 2 & 3 & & 3 & 3 & 3 & 3 & 3 & 3 & 2 & 2 & 2 & 2 & 3 & 3 & \\
2 & 2 & 2 & 2 & 3 & 2 & 2 & 3 & 2 & 3 & 3 & 3 & 4 & 4 & 3 & 4 & 4 & 3 & 3 & 4 & 2 & 3 & 4 & \\
& 3 & 3 & 3 & 4 & 2 & 2 & 3 & 3 & 3 & 3 & & 3 & 4 & 4 & 4 & 4 & 4 & 4 & 4 & 4 & 2 & 3 & 4 & \\
& 1 & 1 & 1 & 1 & 1 & 1 & 1 & 1 & 1 & 2 & & 3 & 3 & 3 & 4 & 4 & 4 & 1 & 1 & 1 & 1 & 1 & 1 & \\
3 & 2 & 2 & 2 & 3 & 1 & 1 & 1 & 1 & 1 & 2 & 4 & 4 & 4 & 4 & 4 & 4 & 3 & 3 & 3 & 1 & 1 & 1 & \\
& 3 & 2 & 2 & 3 & 1 & 1 & 1 & 2 & 3 & 3 & 4 & 4 & 4 & 4 & 4 & 4 & 4 & 4 & 4 & 1 & 1 & 1 & \\
& 1 & 2 & 3 & 3 & 2 & 2 & 3 & 2 & 2 & 3 & 4 & 4 & 4 & 4 & 4 & 4 & 4 & 4 & 4 & 2 & 3 & 4 & \\
4 & 2 & 3 & 3 & 4 & 2 & 3 & 4 & 3 & 3 & 4 & 4 & 4 & 4 & 4 & 4 & 4 & 4 & 4 & 4 & 2 & 3 & 4 & \\
& 3 & 4 & 4 & 4 & 2 & 3 & 4 & 3 & 3 & 4 & 4 & 4 & 4 & 4 & 4 & 4 & 4 & 4 & 4 & 2 & 3 & 4 & \\
\hline
\end{tabular}

\section{HASIL PENELITIAN}

Dari 234 dokter gigi yang terdaftar sebagai anggota PDGI Cabang Manado sebanyak 212 orang bersedia berpartisipasi dalam penelitian namun yang memenuhi kriteria inklusi sebanyak 148 responden. Prevalensi NPB pada dokter gigi di Sulawesi Utara didapatkan sebesar $41,2 \%$ (Tabel 3).
Hasil analisis bivariat menunjukkan adanya hubungan bermakna antara posisi bekerja $\quad(p=0,043$, koefisien korelasi $\Phi=0,166)$ dan jumlah pasien per hari $(\mathrm{p}=0,020, \mathrm{r}=0,190)$ dengan NPB. Faktor risiko lainnya yaitu usia $(\mathrm{p}=0,189, \mathrm{r}=0,108)$, jenis kelamin $(\mathrm{p}=0,847$, koefisien korelasi $\Phi=0,016)$, IMT ( $\mathrm{p}=0,249, \mathrm{r}=-0,095)$, kebiasaan olahraga $(\mathrm{p}=0,387$, koefisien korelasi 
$\Phi=-0,071)$, lama bekerja $(p=0,468, \quad r=-$ $0,060)$, lama praktik $(\mathrm{p}=0,278, \mathrm{r}=0,090)$ dan jenis perawatan $(p=0,660$, koefisien korelasi $\Phi=0,036$ ) tidak menunjukkan hubungan bermakna dengan NPB pada dokter gigi di Sulawasi Utara. Pada analisis regresi logistik, variabel yang dimasukkan ialah variabel yang pada analisis bivariat mempunyai nilai $\mathrm{p}<0,25,{ }^{20}$ yaitu usia, IMT, posisi bekerja, dan jumlah pasien per hari. Analisis regresi logistik pada penelitian ini dilakukan dengan metode backward (Tabel 4).

\section{BAHASAN}

Prevalensi NPB pada dokter gigi di Sulawesi Utara yaitu sebesar 41,2\% (Tabel 3). Dari 148 dokter gigi yang menjadi responden, sebanyak 61 orang mengalami NPB. Angka ini dapat diartikan bahwa hampir setengah dokter gigi di Sulawesi Utara menderita NPB. Prevalensi NPB pada dokter gigi di beberapa negara juga menunjukkan persentase tinggi. Penelitian yang dilakukan pada 300 dokter gigi di Tehran Iran, memperoleh prevalensi dokter gigi yang mengalami NPB sebesar $31,4 \% .^{21}$ Samman ${ }^{22}$ melakukan penelitian terhadap 262 dokter gigi di Damascus Siria, dan mendapatkan prevalensi dokter gigi yang menderita NPB sebesar 37,5\%. Penelitian pada dokter gigi di New Delhi menunjukkan prevalensi dokter gigi yang menderita NPB sebesar $69 \%$ atau 45 orang. ${ }^{23}$

Tabel 3. Prevalensi nyeri punggung bawah pada dokter gigi di Sulawesi Utara berdasarkan karakteristik responden

\begin{tabular}{|c|c|c|c|c|c|}
\hline \multirow[t]{3}{*}{ Karakteristik Responden } & & \multicolumn{4}{|c|}{ Nyeri Punggung Bawah } \\
\hline & & \multicolumn{2}{|c|}{$\mathrm{Ya}$} & \multicolumn{2}{|c|}{ Tidak } \\
\hline & & $\mathrm{n}$ & $\%$ & $\mathrm{n}$ & $\%$ \\
\hline \multirow[t]{2}{*}{ Usia } & $\leq 30$ tahun & 31 & 20,9 & 43 & 29,1 \\
\hline & $>30$ tahun & 30 & 20,3 & 44 & 29,7 \\
\hline \multirow[t]{2}{*}{ Jenis kelamin } & Laki-laki & 17 & 11,5 & 23 & 15,6 \\
\hline & Perempuan & 44 & 29,7 & 64 & 43,2 \\
\hline \multirow[t]{4}{*}{ Indeks massa tubuh } & Berat badan kurang & 4 & 2,7 & 5 & 3,4 \\
\hline & Normal & 31 & 20,9 & 51 & 34,4 \\
\hline & Overweight & 21 & 14,2 & 26 & 17,6 \\
\hline & Obesitas & 5 & 3,4 & 5 & 3,4 \\
\hline \multirow[t]{2}{*}{ Perilaku merokok } & Ya & 1 & 0,7 & 0 & 0 \\
\hline & Tidak & 60 & 40,5 & 87 & 58,8 \\
\hline \multirow[t]{2}{*}{ Kebiasaan olahraga } & Ya & 23 & 15,5 & 39 & 26,4 \\
\hline & Tidak & 38 & 26,7 & 48 & 32,4 \\
\hline \multirow[t]{2}{*}{ Posisi bekerja } & Normal & 18 & 12,1 & 40 & 27,0 \\
\hline & Tidak normal & 43 & 29,1 & 47 & 31,8 \\
\hline \multirow[t]{2}{*}{ Lama bekerja per hari } & $\leq 7 \mathrm{jam}$ & 56 & 41,2 & 80 & 54,1 \\
\hline & $>7$ jam & 5 & 3,4 & 7 & 4,7 \\
\hline \multirow[t]{2}{*}{ Jumlah pasien per hari } & $\leq 5$ pasien & 32 & 21,6 & 55 & 37,2 \\
\hline & $>5$ pasien & 29 & 19,6 & 32 & 21,6 \\
\hline \multirow[t]{2}{*}{ Lama praktik } & $<5$ tahun & 34 & 23,0 & 46 & 31,1 \\
\hline & $\geq 5$ tahun & 27 & 18,2 & 41 & 27,7 \\
\hline Jenis perawatan yang paling sering & Berisiko & 56 & 37,8 & 78 & 52,7 \\
\hline dilakukan & Tidak berisiko & 5 & 3,4 & 9 & 6,1 \\
\hline Total & & 61 & 41,2 & 87 & 58,8 \\
\hline
\end{tabular}


Tabel 4. Hasil uji regresi logistik biner

\begin{tabular}{llllllllll}
\hline & & & & & & & & & \multicolumn{2}{c}{$\begin{array}{c}\text { 95\% C.I. for } \\
\text { EXP(B) }\end{array}$} \\
\cline { 7 - 10 } & & B & S.E. & Wald & df & Sig. & Exp(B) & Lower & Upper \\
\hline Step 1 & Usia & $-0,068$ & 0,046 & 2,231 & 1 & 0,135 & 0,934 & 0,854 & 1,022 \\
& IMT & 0,047 & 0,048 & 0,966 & 1 & 0,326 & 10048 & 0,954 & 1,152 \\
& Posisi bekerja & 0,642 & 0,368 & 3,053 & 1 & 0,081 & 10901 & 0,925 & 3,907 \\
& Jumlah pasien & 0,124 & 0,053 & 5,412 & 1 & 0,020 & 10132 & 10020 & 1,258 \\
& Constant & 0,499 & 1,730 & 0,083 & 1 & 0,773 & 0,607 & & \\
Step 2 & Usia & 0,063 & 0,045 & 1,928 & 1 & 0,165 & 0,939 & 0,859 & 1,026 \\
& Posisi bekerja & 0,676 & 0,366 & 3,415 & 1 & 0,065 & 10966 & 0,960 & 4,026 \\
& Jumlah pasien & 0,127 & 0.053 & 5,683 & 1 & 0,017 & 10136 & 10023 & 1,261 \\
& Constant & 0,422 & 1,460 & 0,083 & 1 & 0,773 & 10525 & & \\
Step 3 & Posisi bekerja & 0,735 & 0,362 & 4,128 & 1 & 0,042 & 20085 & 10026 & 4,238 \\
& Jumlah pasien & 0,117 & 0,052 & 5,000 & 1 & 0,025 & 1,124 & 1,015 & 1,245 \\
& Constant & $-1,534$ & 0,439 & 12,213 & 1 & 0,000 & 0,216 & & \\
\hline
\end{tabular}

Prevalensi yang tinggi juga ditunjukkan oleh penelitian yang dilakukan pada 121 dokter gigi di Patna India. Data yang diperoleh menunjukkan bahwa 88 dokter gigi atau $72,80 \%$ mengalami NPB dan nyeri pada leher. Hanya $39,54 \%$ dokter gigi yang mengeluhkan NPB mencari pertolongan medis dan sebesar $57,85 \%$ dokter gigi memilih olahraga dan yoga untuk meredakan nyeri. ${ }^{15}$

Risiko terjadinya NPB akan semakin meningkat seiring dengan bertambahnya usia. Kehilangan kekuatan tulang akibat osteoporosis dapat menyebabkan patah tulang. Selain itu, dengan bertambahnya usia, elastisitas dan tonus otot menurun, diskus intervertebralis mulai kehilangan cairan dan kelenturannya sehingga menurunkan kemampuan untuk melindungi vertebra. $^{24}$

Uji korelasi antara usia dengan NPB menunjukkan tidak terdapat korelasi bermakna antara usia dengan NPB pada dokter gigi di Sulawesi Utara $(p=0,189)$. Hasil penelitian ini selaras dengan yang dilaporkan oleh Mohseni-Bandpei et $\mathrm{al}^{21}$ yaitu tidak terdapat hubungan bermakna antara usia dengan NPB $(\mathrm{p}=0,411)$. Penelitian yang dilakukan oleh Paldhikar et $\mathrm{al}^{5} \mathrm{di}$ Pune India juga menunjukkan hasil yang sama yaitu tidak terdapat hubungan bermakna antara usia dengan NPB $(\mathrm{p}=0,060)$. Demikian halnya dengan pene- litian oleh Ajwa et $\mathrm{al}^{25}$ di Riyadh terhadap 715 dokter gigi menunjukkan tidak terdapat hubungan bermakna antara usia dengan NPB $(p=0,949)$. Hal ini berbeda dengan hasil penelitian yang dilakukan oleh Ilyas dan Dharmaji ${ }^{26}$ di Makassar terhadap 86 dokter gigi yang menunjukkan adanya hubungan bermakna antara usia dengan NPB $(\mathrm{p}=0,013)$.

Selain faktor usia, jenis kelamin juga dapat meningkatkan risiko NPB. Fluktuasi hormon saat menstruasi dan memasuki usia menopause berperan penting dalam etiologi dan patofisiologi gangguan muskuloskeletal. ${ }^{27}$ Meskipun demikian, hasil penelitian ini menunjukkan tidak terdapat korelasi bermakna antara jenis kelamin dengan NPB $(\mathrm{p}=0,847)$. Hasil tersebut selaras dengan penelitian yang dilakukan oleh MohseniBandpei et $\mathrm{al}^{21}$ terhadap dokter gigi di Iran yang menunjukkan bahwa perempuan lebih banyak mengeluhkan NPB daripada lakilaki. Meskipun demikian, tidak didapatkan hubungan bermakna antara jenis kelamin dengan NPB $(p=0,292)$. Hasil serupa juga dilaporkan pada penelitian di Riyadh yang menunjukkan tidak terdapat hubungan bermakna antara jenis kelamin dengan NPB $(\mathrm{p}=0,963){ }^{25}$

Penelitian yang dilakukan oleh Chandra et $\mathrm{al}^{15}$ pada 121 dokter gigi di Patna India, melaporkan hasil sebesar $60 \%$ laki-laki dan $40 \%$ perempuan mengeluhkan 
NPB dan nyeri pada leher namun pada penelitian tersebut tidak diteliti mengenai hubungan antara jenis kelamin dengan NPB.

Obesitas diketahui dapat menyebabkan kelebihan beban pada struktur artikular tulang belakang lumbar sehingga menyebabkan kecenderungan degenerasi yang mengakibatkan NPB. ${ }^{28}$ Hasil penelitian ini menunjukkan tidak terdapat korelasi bermakna antara IMT dengan NPB $(p=0,249)$. Hal ini sejalan dengan penelitian MohseniBandpei et al $^{21}$ terhadap 300 dokter gigi di Iran yang menunjukkan tidak terdapat hubungan bermakna antara IMT dengan NPB ( $\mathrm{p}=0,071)$. Hasil yang berbeda dilaporkan pada penelitian terhadap dokter gigi di India yang menunjukkan adanya hubungan bermakna antara IMT dengan NPB (p<0,001). ${ }^{5}$

Kurangnya aktivitas fisik dan gaya hidup yang tidak banyak bergerak menyebabkan pengurangan kekuatan otot yang mengarah pada penurunan kemampuan diskus intervertebralis untuk mempertahankan konsentrasi air yang normal sehingga dapat meningkatkan NPB karena punggung menjadi kaku dan lemah. ${ }^{29}$ Namun hasil penelitian ini tidak menunjukkan adanya hubungan bermakna antara kebiasaan olahraga dengan NPB ( $p=0,387$, koefisien korelasi $\Phi=-0,071)$. Hasil penelitian ini sejalan dengan penelitian yang dilakukan oleh Mohseni-Bandpei et $\mathrm{al}^{21}$ terhadap 300 dokter gigi di Iran yang menunjukkan tidak terdapat hubungan bermakna antara kebiasaan olahraga dengan NPB $(\mathrm{p}=0,091)$.

Hasil uji korelasi antara posisi bekerja dengan NPB mendapatkan nilai $\mathrm{p}=0,043$ $(\mathrm{p}<0,05)$ yang menunjukkan terdapat korelasi bermakna antara posisi bekerja dengan NPB. Nilai koefisien korelasi $\Phi=0,166$ dapat diartikan bahwa hubungan antara posisi bekerja dengan NPB tergolong sangat lemah dengan arah korelasi positif. Arah korelasi positif menunjukkan bahwa posisi bekerja yang semakin buruk saat melakukan perawatan kepada pasien, akan meningkatkan risiko terkena NPB pada dokter gigi di Sulawesi Utara.

Hasil serupa juga diperoleh dari pene- litian yang dilakukan terhadap 715 dokter gigi di Riyadh. Penelitian tersebut menunjukkan bahwa NPB secara bermakna berhubungan dengan postur tubuh yang buruk $(\mathrm{p}<0,001){ }^{25}$

Nyeri punggung bawah dapat disebabkan oleh postur statis yang berkepanjangan, gerakan berulang, posisi yang buruk, serta pencahayaan yang kurang optimal. Dokter gigi sering mengambil posisi statis yang memerlukan lebih dari $50 \%$ otot tubuh berkontraksi untuk menahan tubuh agar tidak bergerak sambil melawan gravitasi. Gaya statis yang dihasilkan dari postur ini telah terbukti jauh lebih membebani daripada gaya dinamis (bergerak). Perawatan gigi seringkali membuat dokter gigi mengambil posisi membungkuk ke depan, rotasi kepala, leher dan trunk ke sisi otot yang bertanggung jawab untuk memutar tubuh sehingga satu sisi dapat menjadi lebih kuat dan lebih pendek, sedangkan sisi lain menjadi lebih lemah dan memanjang. Otot yang memendek akan mendapat tekanan sehingga terjadi iskemik dan nyeri. ${ }^{5}$

Hasil uji korelasi antara lama bekerja dengan NPB pada penelitian ini memperoleh nilai $\mathrm{p}=0,468$ yang menunjukkan tidak terdapat korelasi bermakna antara lama bekerja dengan NPB. Hasil serupa dilaporkan pada penelitian yang dilakukan oleh Gaowgzeh et $\mathrm{al}^{6}$ yang menunjukkan tidak terdapat korelasi antara lama bekerja dalam sehari dengan kejadian NPB pada dokter gigi di Arab Saudi. Hasil yang diperoleh pada penelitian ini berbeda dengan penelitian yang dilakukan pada dokter gigi di Pune India yang menunjukkan adanya hubungan bermakna antara lama bekerja dengan NPB $(p<0,001) .^{5}$

Peningkatan jumlah pasien akan meningkatkan frekuensi dan intensitas kerja dokter gigi. Bahkan dengan postur tubuh yang normal sekalipun selama melakukan perawatan pada pasien, NPB bisa terjadi. Semakin banyak jumlah pasien, maka semakin lama dokter gigi bekerja, dan kemungkinan untuk mengalami kelelahan otot lebih besar. ${ }^{26}$ Hasil uji korelasi antara jumlah pasien per hari dengan NPB memperoleh signifikansi sebesar $0,020(p<0,05)$. 
Hal ini menunjukkan adanya korelasi bermakna antara jumlah pasien per hari dengan NPB. Nilai koefisien korelasi $\mathrm{r}=0,190$ dapat diartikan bahwa hubungan antara jumlah pasien per hari dengan NPB tergolong sangat lemah dengan arah korelasi positif, yaitu semakin banyak jumlah pasien yang dirawat dalam sehari, akan meningkatkan risiko terjadinya NPB. Hasil penelitian ini sejalan dengan penelitian yang dilakukan oleh Zarra dan Lambrianidis $^{30}$ terhadap endodontis di Yunani yang menunjukkan bahwa jumlah pasien yang dirawat berhubungan dengan risiko menderita gangguan muskuloskeletal. Pada penelitian tersebut ditemukan bahwa dokter gigi yang merawat 6 sampai 8 pasien per hari berisiko 3,52 kali lebih tinggi untuk mengalami gangguan muskuloskeletal dibandingkan dengan dokter gigi yang merawat kurang dari 6 pasien $(\mathrm{OR}=3,52$; CI 95\%). Hasil yang berbeda dilaporkan oleh Ilyas dan Dharmaji ${ }^{26}$ di Makassar yang menyatakan tidak terdapat hubungan bermakna antara jumlah pasien dengan NPB $(p=0,233)$. Demikian juga dengan penelitian oleh Gaowgzeh et $\mathrm{al}^{6}$ di Arab Saudi yang menyatakan tidak terdapat hubungan antara jumlah pasien yang dirawat dengan NPB. Namun, penelitian yang dilakukan pada 715 dokter gigi di Riyadh menunjukkan adanya hubungan bermakna antara nyeri pada bahu dengan jumlah pasien $(\mathrm{p}=0,030)$ tetapi tidak terdapat hubungan bermakna antara jumlah pasien dengan NPB $(\mathrm{p}=0,054){ }^{25}$

Hasil uji korelasi antara lama praktik dengan NPB memperoleh signifikansi sebesar 0,278 yang menunjukkan tidak terdapat korelasi bermakna antara lama praktik dengan NPB. Hasil yang selaras diungkapkan oleh Gaowgzeh et al $^{6}$ yaitu timbulnya nyeri punggung tidak berkorelasi dengan pengalaman praktik bertahun-tahun. Penelitian yang dilakukan oleh MohseniBandpei et $\mathrm{al}^{21}$ pada 300 dokter gigi di Iran juga menunjukkan hal yang sama yaitu tidak terdapat hubungan bermakna antara lama praktik dengan NPB $(\mathrm{p}=0,49)$. Hasil yang berbeda diperoleh pada penelitian terhadap dokter gigi di Pune India yang menunjukkan adanya hubungan bermakna antara lama praktik dengan NPB $(\mathrm{p}<0,001)^{5}$

Hasil penelitian ini juga menunjukkan tidak terdapat korelasi bermakna antara jenis perawatan yang paling sering ditangani dengan keluhan NPB $(p=0,660$, koefisien korelasi $\phi=0,036)$. Hasil ini sejalan dengan penelitian yang dilakukan oleh Ilyas dan Dharmaji ${ }^{26}$ di Makassar yang menunjukkan tidak terdapat hubungan antara jenis perawatan dengan NPB $(\mathrm{p}=0,658)$.

Pada penelitian ini tindakan restorasi dan pencabutan gigi dikategorikan sebagai jenis perawatan yang berisiko, sedangkan skeling dan perawatan ortodonti sebagai jenis perawatan yang tidak berisiko. Restorasi gigi cenderung memerlukan waktu pengerjaan yang cukup panjang dan ketelitian tinggi, sehingga menyebabkan seorang dokter gigi duduk statis dalam waktu lama, sedangkan pencabutan gigi seringkali membuat dokter gigi membungkuk ke arah pasien, memutar tubuh dan bergerak secara mendadak. $^{31}$

Hasil analisis multivariat menunjukkan bahwa faktor yang paling berpengaruh terhadap terjadinya NPB pada dokter gigi di Sulawesi Utara yaitu posisi bekerja dengan $\mathrm{p}=0,043$ dan nilai $\mathrm{OR}=2,085$ (Tabel 13). Hal ini dapat diartikan bahwa dokter gigi yang melakukan perawatan gigi dengan posisi kerja tidak normal memiliki risiko 2,085 kali lebih besar untuk mengalami NPB dibanding dokter gigi yang melakukan pekerjaannya dengan posisi normal. Temuan ini sejalan dengan penelitian oleh Zarra dan Lambrianidis ${ }^{30}$ pada dokter gigi di Yunani yang menunjukkan bahwa dokter gigi yang bekerja dengan postur tubuh canggung selama praktik berisiko 4,56 kali lebih tinggi mengalami gangguan muskuloskeletal daripada dokter gigi dengan posisi kerja normal $(\mathrm{OR}=4,561, \mathrm{CI}=95 \%)$. Penelitian yang dilakukan di RS X di Surabaya menunjukkan adanya hubungan yang cukup kuat antara sikap kerja dokter gigi dengan keluhan NPB. ${ }^{32}$ Hasil penelitian pada tenaga kesehatan gigi di Malaysia menunjukkan hasil serupa yaitu postur 
tubuh yang buruk berisiko 3 kali lebih besar untuk mengalami NPB dibanding yang melakukan pekerjaannya dengan postur tubuh yang baik $(\mathrm{OR}=3,52) .{ }^{33}$

Perubahan fisiologik yang merugikan dan serius dapat terjadi akibat postur tubuh yang tidak normal saat melakukan perawatan gigi pada pasien, termasuk ketidakseimbangan otot, nekrosis otot, trigger point, hypomobile joint, nerve compression, dan herniasi atau degenerasi diskus. Perubahan ini seringkali mengakibatkan rasa nyeri, terutama cedera pada punggung. ${ }^{5}$

Tindakan pencegahan NPB dalam kedokteran gigi memerlukan perubahan kebiasaan kerja, penggunaan peralatan yang ergonomis, dan melakukan peregangan. Selama prosedur klinis, dokter gigi harus memperoleh postur yang ideal sehingga tekanan pada struktur tulang belakang dan energi otot yang dikeluarkan minimal. Dengan cara ini, dokter gigi dapat meningkatkan efisiensi kerja yang pada akhirnya akan meningkatkan kualitas perawatan gigi pada pasien.

\section{SIMPULAN}

Posisi kerja merupakan faktor yang paling berpengaruh terhadap NPB pada dokter gigi di Sulawesi Utara $(\mathrm{OR}=2,085$, $\mathrm{CI}=95 \%$ ). Diharapkan bagi seluruh dokter gigi untuk menghindari posisi kerja yang dapat membahayakan sistem muskuloskeletal saat melakukan perawatan kepada pasien.

\section{Keterbatasan Penelitian}

Penilaian sikap tubuh dengan metode OWAS seharusnya dilakukan dengan cara mengamati sikap tubuh responden secara langsung. Hal tersebut tidak memungkinkan untuk dilakukan dalam masa pandemi Covid-19 karena risiko terpapar yang tinggi disebabkan sebagian besar perawatan gigi dan mulut menghasilkan aerosol yang menjadi media utama penularan Covid-19.

\section{Konflik Kepentingan}

Penulis menyatakan tidak terdapat konflik kepentingan dalam penelitian ini.

\section{DAFTAR PUSTAKA}

1. Reddy KS, Majumder DSP, Doshi D, Kulkarni S, Reddy BS, Reddy MP. Occupational hazards in dentistry. J Res Adv Dent. 2017;6(2):110-22.

2. Moodley R, Naidoo S, Van J. The prevalence of occupational health-related problems in dentistry: A review of the literature. $\mathrm{J}$ Occup Health [serial online]. 2018; 60(2):111-25. Available from: doi: 10.1539/joh.17-0188-RA.

3. Damian A. Gambaran distribusi kejadian nyeri punggung bawah "low back pain" pada dokter gigi di Kota Yogyakarta [Tesis]. Yogyakarta: Universitas Muhammadiyah Yogyakarta; 2018.

4. Kaur J, Manoj M, Punia S, Yogesh. Prevalence of back pain and neck pain among dentists in Hisar, India. International Journal of Health Sciences \& Research. 2018;146(8):6.

5. Paldhikar S, Bhatkar S, Ghodey S. Incidence and study of occupational factors associated with low back pain in dentists in Pune Region India. IOSR Journal of Dental and Medical Sciences (JDMS). 2012;3(2):8-12.

6. Gaowgzeh R, Chevidikunnan AMF, Al Saif SA. El-Gendy, Gama, Al Senany SA. Prevalence of and risk factors for low back pain among dentists. J Phys. Ther Sci. 2015:27(9):2804.

7. Ulya T. Hubungan posisi kerja duduk dengan keluhan nyeri punggung bawah pada dokter gigi saat melakukan tindakan penambalan gigi posterior kiri rahang atas di puskesmas wilayah kerja Surabaya Selatan. [Tesis]. Surabaya: Universitas Airlangga; 2016.

8. Sawitri MR, Mulyono. Analisis risiko pada pekerjaan dokter gigi di kabupaten dan kota Probolinggo. The Indonesian Journal of Occupational Safety and Health (IJOSH). 2019;8(1):29-37.

9. Wulandari RA, Pertiwi JM, Khosama H. Gambaran faktor yang mempengaruhi nyeri punggung bawah pada buruh kapal. e-CliniC. 2014;2(1).

10. Walker SD, Brown HL, Thiese MS, Ott U, Wood JE, Kapellusch, et al. Association between exercise and low back pain resulting in modified duty and lost time. J Occup Environ Med. 2018; 60(10):896-900. Doi: 10.1097/JOM. 0000000000001372. Available from: 
doi:10.1097/jom. 00000000000013

11. Grabovac I, Dorner TE. Association between low back pain and various everyday performances. Wien Klin Wochenschr. 2019;131:541-9. Available from: https://doi.org/10.1007/s00508-01901542-7

12. Dagenais S, Haldeman S. Evidence-Based Management of Low Back Pain. Philadelphia: Elsevier Mosby, 2012; p. 560. Available from: https://www.ncbi.nlm. nih.gov/pmc/articles/PMC3581015/

13. Meman SH, Pais V, Kalal BS. Physical risk factors for low back pain among young sedentary individuals - a prospective study. Indian J Pain. 2017;31(3):15763.

14. Wulandari MD, Setyawan, Zubaidi A. Faktor risiko nyeri punggung bawah pada mahasiswa Jurusan Ortotik Prostetik Politeknik Kesehatan Surakarta. Jurnal Keterapian Fisik. 2017;2(1):8-14.

15. Chandra SA. Shahi K, Bhargava R. Prevalence of neck and lower back pain among dentists from three dental colleges in Patna City: a questionnaire study. Int J Sci Study. 2015;3(8):71-6.

16. De Sio S, Traversini V, Rinaldo F, Colasanti V, Buomprisco G, Perri R, et al. Ergonomic risk and preventive measures of musculoskeletal disorders in the dentistry environment: an umbrella review. PeerJ. 2018;15(6).

17. Sekretariat Persatuan Dokter Gigi Indonesia (PDGI) Cabang Manado. 2020. Daftar anggota PDGI Cabang Manado.

18. Sriyanto, Adwitya W. Analisis postur kerja menggunakan metode Ovako Work Posture Analysis System (OWAS) (Studi Kasus: PT Sanggar Sarana Baja Transporter). Industrial Engineering Journal. 2018;7(2).

19. Karhu O, Kansi P, Kuorinka I. Correcting working postures in industry: a practical method for analysis. Applied Ergonomics.1977;8(4):122-201. Doi:10.1016/0003-6870(77)90164-8.

20. Dahlan MS. Statistik untuk Kedokteran dan Kesehatan. Jakarta: Salemba Medika, 2011; p. 22.

21. Mohseni-Bandpei MA, Rahmani N, Halimi F, Farooq MN. The prevalence of low back pain in Iranian dentists: an epidemiological study. Pakistan Journal of Medical Sciences. 2017;33(2):280-4.
Available from: https://doi.org/10. 12669/pjms.332.11519.

22. Samman O. The effect of work posture on developing low back pain, neck pain among dentists A cross sectional survey among dentists in Damascus, Syria. [Dissertation]. Damascus Syria: Centre for Strategic Health Studies, Damascus. Syria; 2011. Available from:https:// www.researchgate.net/publication/2339 53653_The_effect_of_work_posture_o n_developing_low_back_pain_neck_pa in_among_dentists_A_cross_sectional_ survey_among_dentists_in_Damascus_ Syria/link/09e4150d49fab9ed20000000 /download

23. Beg MA, Kakroo SN, Jamal A. A study on prevalence of and risk factors for low back pain among dentists. International Archives of BioMedical and Clinical Research. 2018;4(2):138-40. Available from: https://doi.org/10.21276/iabcr. 2018.4.2.40

24. National Institute of Neurological Disorders and Stroke/NINDS. Nyeri Punggung Bawah Fact Sheet. 2020. Available from: https://www.ninds.nih.gov/ Disorders/Patient-Caregiver-Education/ Fact-Sheets/Low-Back-Pain-FactSheet\#: :text=Chronic\%20back\%20pai n\%20is\%20defined,persistent\%20symp toms\%20at\%20one\%20year.

25. Ajwa N, Al Khunaizi F, Al Orayyidh A, Al Qattan W, Bujbarah F, Bukhames G, et al. Neck and back pain as reported by dental practitioners in Riyadh city. $\mathrm{J}$ Dent Health Oral Disord Ther. 2018; 9(4):340-5. Doi: 10.15406/jdhodt.2018. 09.00405 .

26. Ilyas M, Dharmaji TP. Low back pain in dentists of Indonesia. Pakistan Oral \& Dental Journal. 2012;32(3):464-8.

27. Wang YX, Wang J, Kaplar Z. Increased low back pain prevalence in females than in males after menopause age: evidences based on synthetic literature review. Quant Imaging Med Surg. 2016;6(2): 199-206. Doi: 10.21037/qims.2016. 04.06.

28. Ramdas J, Jella V. Prevalence and risk factors of low back pain. Int J Adv Med. 2018; 5(5):1-4. Doi: http://dx.doi.org/10. 18203/2349-3933.ijam20183413

29. Azfar S, Murad M, Azim S. Rapid assessment of physical activity and its association 
among patients with low back pain. Cureus.2019;11(12):6373.

Doi:10.7759/cureus.6373.

30. Zarra T, Lambrianidis T. Musculoskeletal disorders amongst Greek endodontists: a national questionnaire survey. Int Endod J. 2013;47(8):791-801. pmid: 24283200

31. Andayasari L, Anorital. Gangguan muskuloskeletal pada praktik dokter gigi dan upaya pencegahannya. Media Litbang Kesehatan. 2012;22(2):70-7.

32. Refresitaningrum, Paskarini I. Analisa sikap kerja dokter gigi yang berhubungan dengan keluhan nyeri pinggang di rumah sakit X Surabaya. JPH Recode. 2108;1(2):24-32.

33. Samat RA, Shafei MN, Yaacob NA, Yusoff A. Prevalence and associated factors of back pain among dental personnel in North-Eastern State of Malaysia. International Journal of Collaborative Research on Internal Medicine \& Public Health. 2011;3(7):576-86. Available from: http://iomcworld.com/ ijcrimph/ijcrimph-v03-n07-03.htm 